\title{
Gastrointestinal Immune Response to the Shrimp Allergen Tropomyosin: Histological and Immunological Analysis in an Animal Model of Shrimp Tropomyosin Hypersensitivity
}

\author{
Yin Fan Lam ${ }^{\mathrm{a}}$ Ka Kui Tong ${ }^{\mathrm{a}}$ Kin Ming Kwan ${ }^{\mathrm{a}-\mathrm{c}}$ Koichi Tsuneyama ${ }^{\mathrm{d}}$ \\ Shang-AnShue Patrick S.C. Leung ${ }^{e} \mathrm{Ka} \mathrm{Hou} \mathrm{Chu}^{\mathrm{a}}$

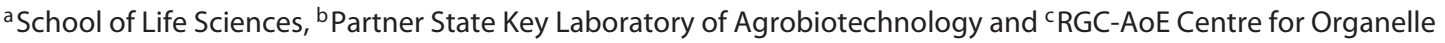 \\ Biogenesis and Function, The Chinese University of Hong Kong, Hong Kong SAR, China; ${ }^{d}$ Molecular and \\ Environmental Pathology, Institute of Health Bioscience, The University of Tokushima Graduate School, Tokushima, \\ Japan; ${ }^{e}$ Division of Rheumatology/Allergy and Clinical Immunology, School of Medicine, University of California, \\ Davis, Calif., USA
}

\section{Key Words}

Seafood allergy · Tropomyosin · Mucosal immunology ·

Cytokines

\begin{abstract}
Background: Shellfish hypersensitivity is among the most common food allergies. A murine model of IgE-mediated shrimp allergy has been established in our laboratory. The aim of this study is to determine the intestinal histological changes and cytokine expression profile of this model sensitized with the major shellfish allergen tropomyosin. Methods: Female Balb/c mice orally sensitized and challenged with recombinant tropomyosin were sacrificed. Continuous sections of duodenum, jejunum and ileum were prepared using the Swiss roll technique for histological and immunological analysis. Duodenal epithelial cell apoptosis and migration were examined. mRNA expression of IL-4, IL-6, IL-10, IL-13, IL-18 and IFN- $\gamma$ in intestinal tissue was measured via RT-PCR. Results: In tropomyosin-sensitized and challenged mice, an increased number of eosinophils, mast cells and
\end{abstract}

\section{KARGER 125}

2015 S. Karger AG, Base

$1018-2438 / 15 / 1671-0029 \$ 39.50 / 0$

E-Mail karger@karger.com

www.karger.com/iaa goblet cells was found $24 \mathrm{~h}$ after challenge. There were also increased mast cell and goblet cell numbers at $72 \mathrm{~h}$ after challenge, but the level of eosinophils decreased. Differences compared with control mice are most prominent at the duodenum compared to the distal regions. In addition, TUNEL assay indicates a significantly higher apoptosis rate in sensitized mice sacrificed $72 \mathrm{~h}$ after challenge, and mRNA expression showed a biased Th2/Th1 cytokine profile and a higher level of murine mast cell protease 1. Conclusions: This study documented a multitude of histological and immunological changes in the gut in a murine model of shrimp allergy. Even without repetitive intragastric challenge, shrimp tropomyosin induces an increase in the number of inflammatory cells to varying degrees within the small intestine. This model provides an important tool for testing new therapeutic interventions.

(c) 2015 S. Karger AG, Basel
Correspondence to: Dr. Ka Hou Chu

School of Life Sciences, The Chinese University of Hong Kong Shatin, NT, Hong Kong SAR (China) E-Mail kahouchu@cuhk.edu.hk

Dr. Patrick S.C. Leung

Division of Rheumatology/Allergy and Clinical Immunology

School of Medicine, University of California

451, Health Science Drive, Davis, CA 95616 (USA)

E-Mail psleung@ucdavis.edu 


\section{Introduction}

Shellfish hypersensitivity is one of the most common food allergies [1-4]. It is the most self-reported food allergy in Canada, affecting 1.9\% of the adult population [1]. In teenagers in Singapore and the Philippines, the prevalence of shellfish allergy can be as high as 5.2\% [2]. In subjects with shellfish allergy, allergic symptoms are usually manifested within minutes after ingestion and usually within the first $2 \mathrm{~h} \mathrm{[5].} \mathrm{They} \mathrm{include} \mathrm{cutaneous,}$ digestive and respiratory symptoms, as well as oral allergy syndrome and anaphylaxis [6].

To date, no effective therapeutic strategies for food allergy have been developed and patients are subjected to strict dietary avoidance. Although the major clinical symptoms of shellfish allergy are within the gastrointestinal tract, detailed histological and immunological studies on the gut with regard to seafood hypersensitivity are limited. Intestinal endoscopic and biopsy studies performed on allergic patients demonstrate the presence of mucosal lesions, lymphoid hyperplasia and an elevated tryptase (mast cell mediator) level in the lower gastrointestinal tract [7-9]. Histological studies from biopsies illustrate diarrhea-associated infiltration of inflammatory cells in the duodenum and colon $[7,10,11]$.

Animal models are useful tools for examining the histological changes and underlying mechanisms of pathogenesis in food allergies [12, 13]. For example, the presence of abnormal villi, infiltration of effector cells and hyperplasia of mucus-secreting cells can be identified in the small intestine [14-16] and histological changes can be seen after the application of potential remedies such as the anti-Siglec-F antibody and Pim 1 kinase inhibitor [15, 16].

The major shellfish allergen has been identified as tropomyosin from the shrimp Metapenaeus ensis, Met e 1 [17]. Tropomyosin is a pan-allergen, with highly conserved amino acid sequences and cross-reactivity among shellfish [18]. A murine model of shrimp hypersensitivity has been developed by sensitizing the mice with recombinant Met e 1 [19]. Multiple parameters, including systemic anaphylaxis response assessment, shrimp tropomyosin-specific IgE determination, passive cutaneous anaphylaxis test, splenocyte $\mathrm{T}$ cell proliferation and cytokine profiles, were used to confirm the allergen-specific immunological changes of tropomyosin sensitization. In this study, we further examined the pathohistological and immunological features of the gut in this mouse model. Here, we report our findings on these immunological responses, including the histological analysis of major im- mune cell players, including mast cells, eosinophils and epithelial cells, and the cytokine expression profile in the small intestine after intragastric administration of Met $\mathrm{e}$ 1. Results from this study provide an important tool for evaluating the immunopathogenic mechanisms involved in shellfish hypersensitivity and for the development of therapeutic interventions.

\section{Materials and Methods}

Sensitization and Challenge of Mice

Female Balb/c mice, 3-4 weeks of age, were acquired from the Laboratory Animal Services Centre at The Chinese University of Hong Kong (Hong Kong SAR, China). The mice were maintained on a shrimp-free diet. Animal protocols were approved by the Department of Health under the Hong Kong SAR Government, China.

The experimental protocol for sensitization and challenge of the animals with shrimp tropomyosin has been described [19]. Recombinant shrimp tropomyosin protein (rMet e 1) was prepared using the HisPur Cobalt Agarose Resin (Thermo Scientific) according to the manufacturer's instructions. In the treatment group, mice ( $\mathrm{n}=12$; referred to as the 'Trop' group) were sensitized with $0.1 \mathrm{mg}$ of His-tagged fusion protein of rMet e 1 by intragastric gavage on days $0,12,19$ and 26 (fig. 1a). Ten micrograms of cholera toxin $(\mathrm{CT})$ per mouse was used as adjuvant. One week after the final sensitization (day 33), mice were fasted overnight and challenged with intragastric administration of $0.5 \mathrm{mg}$ rMet e 1 . Mice fed with phosphate-buffered saline (PBS) + CT (PBS group, $n=6)$ were included as a negative control. Mice were sacrificed either 24 (day 34) or $72 \mathrm{~h}$ (day 36) after challenge.

Assessment of Systemic Anaphylaxis and Diarrhea

Anaphylactic symptoms were evaluated at 30-45 min after the oral challenge, according to a previously reported scoring system [14]. Mice demonstrating profuse liquid feces within $1 \mathrm{~h}$ after challenge were recorded as diarrhea positive [20].

\section{Determination of Shrimp Tropomyosin-Specific IgE}

The levels of shrimp tropomyosin-specific IgE were measured by ELISA at 1:5 sera dilution [19]. All assays were performed in duplicate. An irrelevant antigen (ovalbumin; OVA) was used as control. Tropomyosin-sensitized and challenged mice with high levels of tropomyosin-specific IgE (ODs above 0.5 on ELISA) were selected for the following studies.

\section{Histology}

Upon sacrifice, the entire small intestine was collected and flushed by PBS to remove luminal contents using a blunt-ended feeding tube with a $25-\mathrm{ml}$ syringe. Intestines were then flushed and prefixed with $4 \%$ paraformaldehyde for $4 \mathrm{~h}$. Each intestine was divided into three parts (i.e. the duodenum, jejunum and ileum) and cut longitudinally. Each segment was prepared by the Swiss roll method [21], fixed with $4 \%$ paraformaldehyde overnight at $4^{\circ} \mathrm{C}$ and thereafter changed to PBS and stored at $4^{\circ} \mathrm{C}$ before being embedded in paraffin. Tissue sections $(4 \mu \mathrm{m})$ were prepared and mucosal mast cells were identified by Naphthol AS-D chloroacetate esterase staining kit (Sigma-Aldrich) [22]. Three randomly selected areas (ex- 
cluding those with obliquely sectioned villi that showed more than one layer of crypt) of the three intestinal segments were counted in each slide. Slides were stained with periodic acid-Schiff (PAS) [23] for detection of mucus-containing cells. At least 10 randomly selected villi were counted per slide. Quantification of target cells was performed with a Leica microscope and the software ImageJ.

\section{Immunohistochemistry}

Eosinophils and CD4+ T cells were detected using affinity purified rat anti-mouse major basic protein (MBP) monoclonal antibody (provided by Dr. J.J. Lee, Mayo Clinic) and rabbit anti-mouse CD4 antibody (Bioworld Technology). Tissue sections were rehydrated and subjected to specific antigen retrieval treatment. For $\mathrm{MBP}$, pepsin solution ( $\mathrm{pH} 2.1$; Abcam) was used. For CD4, Immunosaver solution (Nisshin EM) was used. Endogenous peroxidase activity was blocked with $\mathrm{H}_{2} \mathrm{O}_{2} / \mathrm{PBS}$. For MBP immunohistochemistry (IHC), tissues were blocked with $10 \%$ heat-inactivated sheep serum in PBS and incubated overnight with the primary antibody (diluted 1:15,000), washed and incubated with affinity purified secondary antibody (diluted 1:250; Millipore). After washing, sections were incubated in DAB color developing solution (Dako). Then, sections were lightly counterstained with hematoxylin and dehydrated. Negative controls included omission of the primary antibody. CD4 immunostain was conducted using the intermittent irradiation method [24]. The number of eosinophils and CD4+ T cells was quantified using methods as described above for mast cells.

\section{Analysis of Intestinal Mucosal Epithelial Cell Proliferation}

Duodenal rolls were subjected to IHC using anti-bromo-2-deoxyuridine (BrdU) antibody (Abcam) and rabbit anti-phosphohistone H3 (PH3P) antibodies (diluted 1:1,250; Millipore). BrdU in PBS was injected intraperitoneally $(0.2 \mathrm{mg} / \mathrm{g}$ body weight $)$ and mice were sacrificed $24 \mathrm{~h}$ later. Sodium citrate buffer ( $\mathrm{pH}$ 6.0) was used for antigen retrieval. Twenty-five well-oriented villus-crypt units per jejunum per mouse were examined for BrdU+ cell quantification. To quantify intestinal epithelial migration, the distance from the crypt base to the farthest BrdU+ epithelial cell of 10 crypts was measured as described by Wu et al. [25]. Crypt epithelial cells with grossly brown-stained nuclei were classified as BrdU positive, whereas cells with blue-stained nuclei were categorized as BrdU negative.

\section{Apoptosis Assay}

Apoptotic cells were detected by the TUNEL assay (Roche Diagnostics). Briefly, after rehydration, 8 - $\mu \mathrm{m}$ sections were permeabilized with Proteinase K $(20 \mu \mathrm{g} / \mathrm{ml}$; Sigma-Aldrich $)$ at room temperature for $25 \mathrm{~min}$ and then rinsed with PBS. Terminal deoxynucleotide transferase mixture was diluted 1:2 with PBS to reduce nonspecific background staining. Sections were incubated with the enzyme mixture, followed by saline citrate, for $15 \mathrm{~min}$ [26], rinsed and then incubated with $1 \%$ bovine serum albumin (BSA) in PBS for $10 \mathrm{~min}$. Endogenous peroxidase activity was then blocked by $1 \% \mathrm{H}_{2} \mathrm{O}_{2}$ treatment for $5 \mathrm{~min}$. Sections were then incubated with anti-fluorescein antibody conjugated with horseradish peroxidase (diluted 1:1 with $1 \%$ BSA/PBS). The apoptotic rate in crypt cells was quantified as the percentage of apoptotic cells in each crypt with analysis restricted to 'intact' longitudinal crypt sections in which the base of the crypt was aligned with all the other crypt bases and the lumen [27].

Intestinal Response to Shrimp Allergen

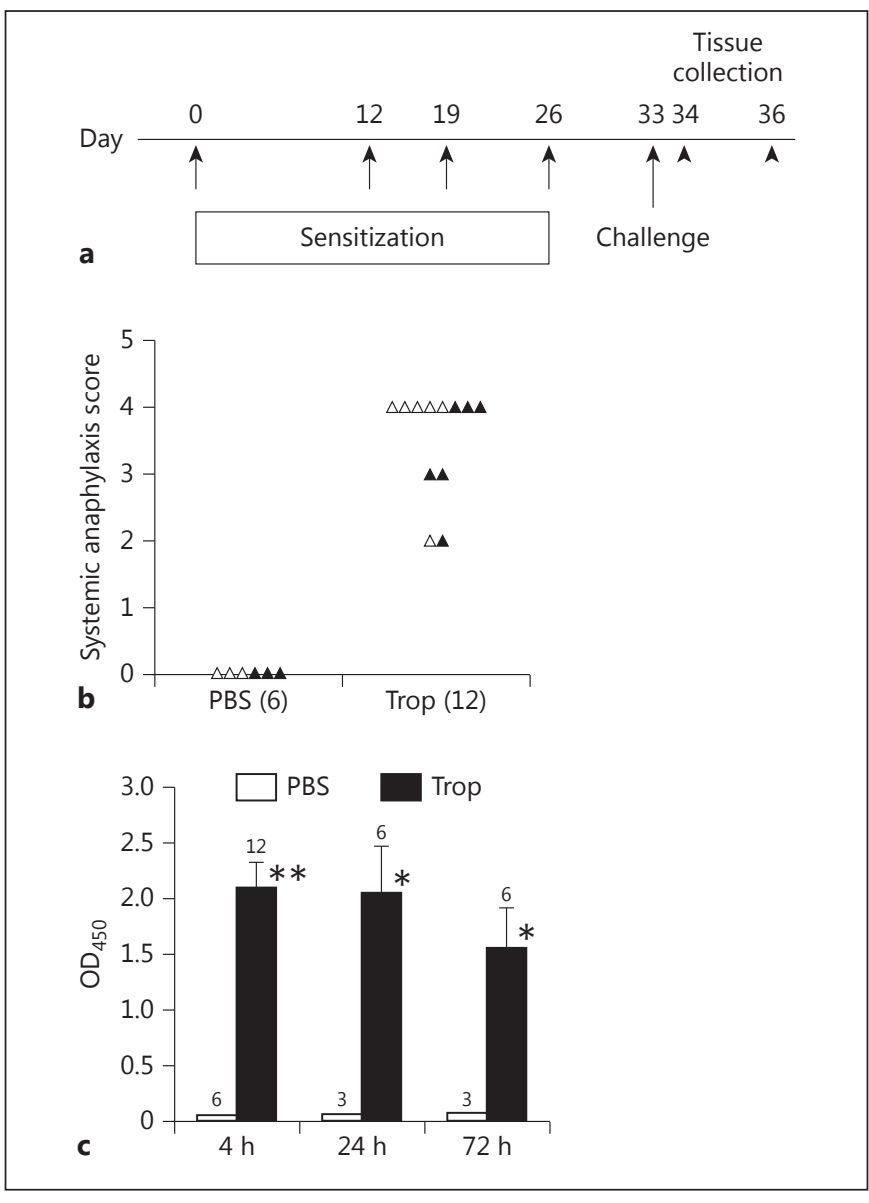

Fig. 1. a Protocol for induction of tropomyosin-induced intestinal allergy. Mice were sensitized intragastrically with recombinant shrimp tropomyosin and CT (Trop group) on days 0, 12, 19, 26 (small arrows) and challenged on day 33 (large arrow). Mice fed with PBS and CT (PBS group) were studied in parallel as a control. Mice were sacrificed either 24 or $72 \mathrm{~h}$ after challenge, i.e. day 34 or 36 (arrowheads). b Systemic anaphylaxis responses after intragastric challenge. Responses of mice were evaluated at 30-40 min after challenge based on a scoring system [14]. Six and 12 mice were included in the PBS and Trop groups, respectively (each symbol representing an individual mouse); half of the mice were sacrificed at $24 \mathrm{~h}$ after challenge (open symbols) and the other half at $72 \mathrm{~h}$ (solid symbols). c Serum levels of recombinant shrimp tropomyosin-specific IgE in mice. Sera from different groups of mice were collected 4, 24 and $72 \mathrm{~h}$ after challenge. The tropomyosin-specific IgE level was determined by ELISA at 1:5 sera dilution. Data are expressed as the mean \pm SEM. ${ }^{*} \mathrm{p}<0.05,{ }^{* *} \mathrm{p}<0.001$ compared with control mice.

\section{Quantitative Real-Time PCR}

RNA was extracted from small intestine tissues $10 \mathrm{~cm}$ from the end of the stomach (the junction between the duodenum and jejunum segments taken for histological studies) using the RNeasy Protect Mini Kit (Qiagen). The concentration and purity of purified total RNA were determined by $\mathrm{OD}_{260 \mathrm{~nm}}$ and the 


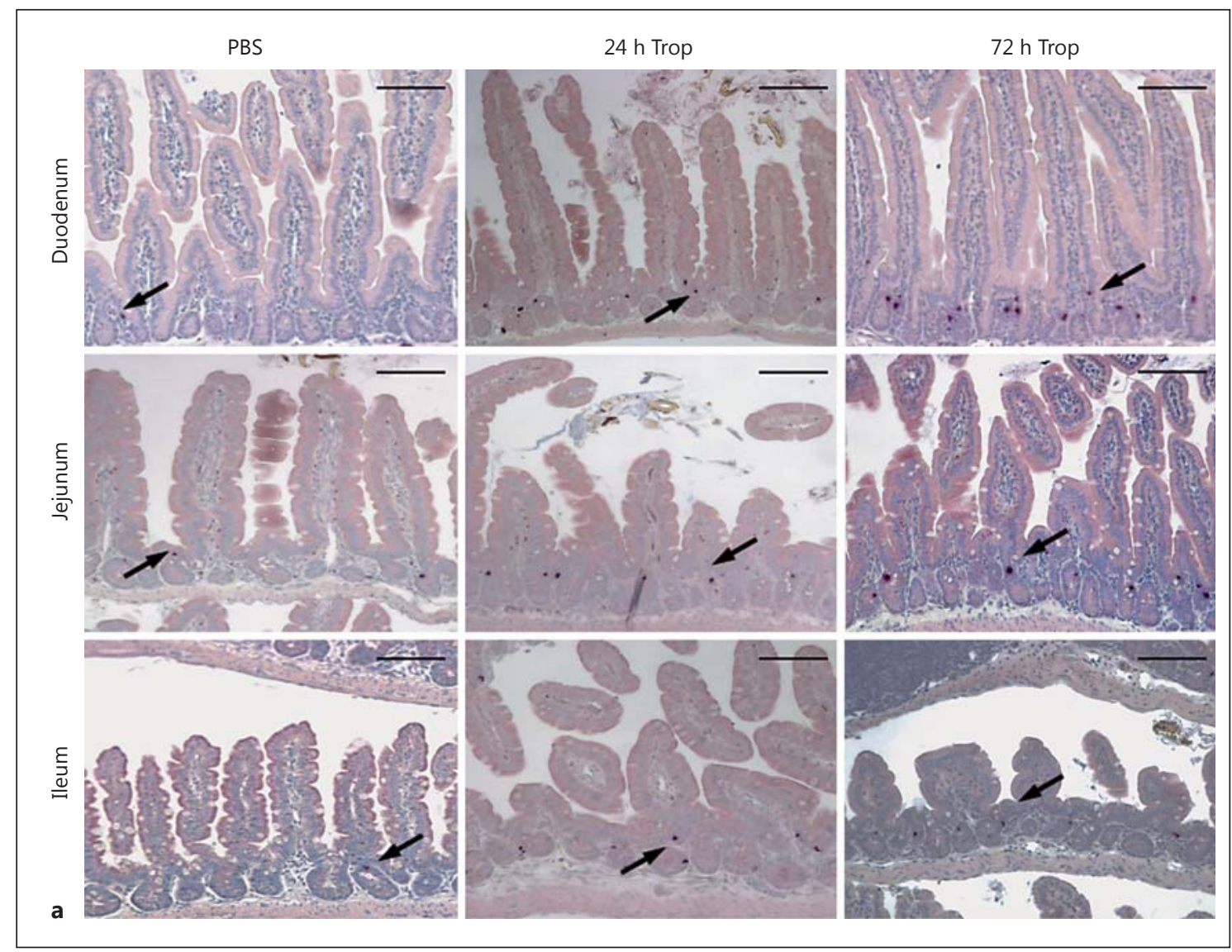

Fig. 2. Sensitizing and challenging mouse with tropomyosin increased mast cell accumulation (arrows indicate mast cells stained red in chloroacetate esterase staining) in the small intestine mucosa. a Representative sections of the duodenum, jejunum and ileum of a PBS control mouse (left) and tropomyosin-sensitized mice, 24 (middle) and $72 \mathrm{~h}$ (right) after challenge. b Quantification of mast cell numbers in the three parts of the small intestine of control $(\mathrm{n}=3)$ and sensitized mice $(\mathrm{n}=6){ }^{*} \mathrm{p}<0.05,{ }^{* *} \mathrm{p}<0.005$ compared with control mice. Data are expressed as the mean \pm SEM. Scale bars $=100 \mu \mathrm{m}$.

$\mathrm{OD}_{260 \mathrm{~nm}} / \mathrm{OD}_{280 \mathrm{~nm}}$ ratio, respectively. Total RNA was reversely transcribed into complementary DNA (TaKaRa). PCR primers for murine IL-4, IL-6, IL-10, IL-13, IL-18, IFN- $\gamma$, murine mast cell protease 1 (mMCP-1) and hypoxanthine phosphoribosyltransferase 1 (HPRT1) were synthesized according to the literature (online suppl. table S1; see www.karger.com/doi/10.1159/000431228 for

all online suppl. material). QuantiTect Primer Assay was used for TNF (Qiagen). Quantitative real-time PCR was performed on an ABI 7500 Fast Real-Time PCR System (Applied Biosystems). All samples were measured in triplicate. Relative quantification of mRNA expression was calculated using the $\Delta \Delta$ cycle threshold method. HPRT1 was chosen as the endogenous reference gene. 
Statistical Analysis

Data are presented as the mean \pm SEM. The statistical significance of the data was determined by either the $t$ test or the MannWhitney U test (for nonparametric comparison) using SigmaStat 11.0 (Systat Software Inc.). A p value $<0.05$ was considered significant.

\section{Results}

Met e 1-Sensitized Mice Exhibited Allergen-Specific

Hypersensitive Responses to Met e 1

Systemic anaphylactic responses were observed after challenge on day 33 (fig. 1b). All rMet e 1-sensitized mice exhibited allergic symptoms, including cutaneous reaction with puffiness around the eyes and snout (score 2), wheezing and respiratory symptoms such as labored respiration and reduced activities (score 3 ), and convulsions and tremors (score 4). These symptoms became obvious in the sensitized mice at 30-45 min after challenge. No animals died after challenge (score 5). Mice from the PBS group did not show any symptoms of anaphylaxis during the course of sensitization and challenge. Five out of 12 tropomyosin-sensitized mice (41.7\%) had diarrhea within $1 \mathrm{~h}$ after challenge.

\section{Elevated Levels of Shrimp Tropomyosin-Specific IgE}

Increased levels of shrimp tropomyosin-specific IgE were observed in mice sensitized and challenged with shrimp tropomyosin (fig. 1c). The levels were significantly different from those of the control mice at $4(\mathrm{p}<0.001)$, $24(\mathrm{p}<0.05)$ and $72 \mathrm{~h}(\mathrm{p}<0.05)$ after challenge. Sustained high levels of IgE were revealed in the sensitized mice after challenge.

\section{Increase in Mast Cell and Eosinophil Infiltration after}

Challenge with Met e 1

The number of intestinal mast cells in tropomyosinsensitized mice $(n=6)$ was compared with those in the control mice $(n=3) 24$ and $72 \mathrm{~h}$ after challenge (fig. 2a). Mast cells accumulated at the crypt level of the mucosa in a patchy pattern. At $24 \mathrm{~h}$, a significant increase in the number of mast cells was found in all three segments of the small intestine, with the highest number being in the duodenum ( $125 \pm 14$ vs. $53 \pm 3$ mast cells $/ \mathrm{mm}^{2} ; \mathrm{p}<0.05$; fig. $2 \mathrm{~b}$ ), while the jejunum and ileum exhibited similar values. The accumulation of mast cells peaked at $72 \mathrm{~h}$ after challenge in the duodenum (158 \pm 14 vs. $35 \pm 5$ mast cells $\left./ \mathrm{mm}^{2} ; \mathrm{p}<0.001\right)$.

Eosinophil infiltration into the mucosa was observed in tropomyosin-sensitized mice when their mucosa was compared with those of control mice (fig. 3a). The number of eosinophils peaked at $24 \mathrm{~h}$ after challenge in the duodenum $\left(2,665 \pm 164\right.$ vs. $784 \pm 26$ eosinophils $/ \mathrm{mm}^{2}$; $\mathrm{p}<0.001$; fig. $3 \mathrm{~b})$. Significant elevation in eosinophils also occurred in the jejunum $(1,761 \pm 179$ vs. $566 \pm 74$ eosinophils $\left./ \mathrm{mm}^{2} ; \mathrm{p}<0.01\right)$. At $72 \mathrm{~h}$ after challenge, eosinophil accumulation was decreased in the duodenum $(1,540 \pm$ 113 vs. $927 \pm 115$ eosinophils $/ \mathrm{mm}^{2} ; \mathrm{p}<0.01$ ) but remained elevated in the jejunum. There was no significant difference between the tropomyosin-sensitized mice and the control mice in terms of the number of eosinophils in the ileum at either 24 or $72 \mathrm{~h}$ after challenge. Eosinophil accumulation was mostly found in a patchy pattern rather than randomly. Besides, the eosinophil accumulation was primarily at the lamina propria part of the mucosa.

\section{Goblet Cell Hyperplasia}

Tropomyosin-sensitized mice demonstrated a higher percentage of goblet cells in the epithelium of the duodenum as compared to the control mice (fig. $4 \mathrm{a}$ ) at $24 \mathrm{~h}$ after challenge $(9.27 \pm 0.29$ vs. $7.63 \pm 0.63 \%$ goblet cells; $\mathrm{p}<$ 0.05 ; fig. $4 \mathrm{~b})$. The number of cells peaked at $72 \mathrm{~h}$ after challenge ( $11.40 \pm 0.55$ vs. $6.38 \pm 0.70 \%$ goblet cells; $\mathrm{p}<$ 0.005). The Swiss roll method showed that the jejunum and ileum had highly variable results in different sections from the same individual as well as among different individuals in the same group.

\section{Analysis of Intestinal Mucosal Epithelial Cell \\ Proliferation and Migration}

Since mast cells, eosinophils and goblet cells in the duodenum displayed significantly different characteristics in tropomyosin-sensitized mice, the duodenum was selected for further analysis. Our results revealed no significant differences in epithelial proliferation within the crypts of tropomyosin-sensitized mice compared with the controls (online suppl. fig. S1). The use of PH3P IHC also revealed similar findings. However, when we quantified epithelial cell migration in the duodenum along the villus-crypt axis in tropomyosin-sensitized and control mice, an increased rate (although not a significant one) of epithelial cell migration up the villus-crypt axis of the duodenum was found at $72 \mathrm{~h}$ after challenge but not at $24 \mathrm{~h}$ after challenge.

\section{CD4+ T Cell Inflammation}

A slightly higher level of CD4+ T cells infiltrated into the duodenal mucosa at $72 \mathrm{~h}$ after challenge in tropomyosin-sensitized mice as compared to control mice (online suppl. fig. S2), but the difference was not statistically significant. 


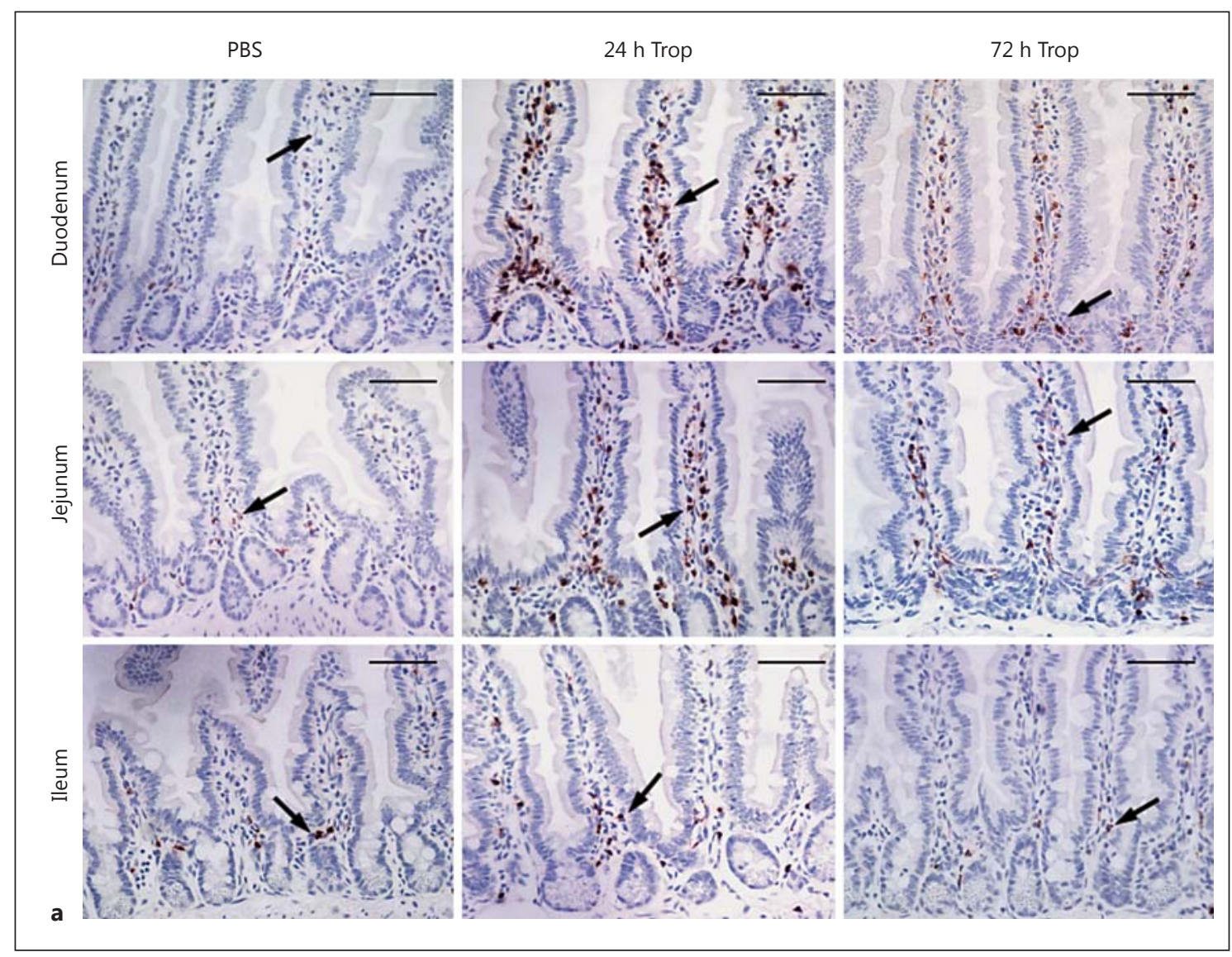

Fig. 3. Sensitizing and challenging mouse with tropomyosin increased eosinophil accumulation (arrows indicate eosinophils stained brown in IHC) in the small intestine mucosa. a Representative sections of the duodenum, jejunum and ileum of a PBS control mouse (left) and tropomyosin-sensitized mice, 24 (middle) and $72 \mathrm{~h}$ (right) after challenge. b Quantification of eosinophil number in the three parts of the small intestine of control $(n=3)$ and sensitized mice $(\mathrm{n}=6){ }^{*} \mathrm{p}<0.05,{ }^{* *} \mathrm{p}<0.005$ compared with control mice. Data are expressed as the mean \pm SEM. Scale bars $=$ $50 \mu \mathrm{m}$.

\section{Number of Apoptotic Cells in the Intestinal Crypts}

We assessed apoptosis of intestinal epithelial cells in the duodenum (fig. 5b) and demonstrated a significant increase in the number of apoptotic TUNEL+ cells in the crypts (98 \pm 8 vs. $30 \pm 10$ TUNEL+ cells/100 crypts;

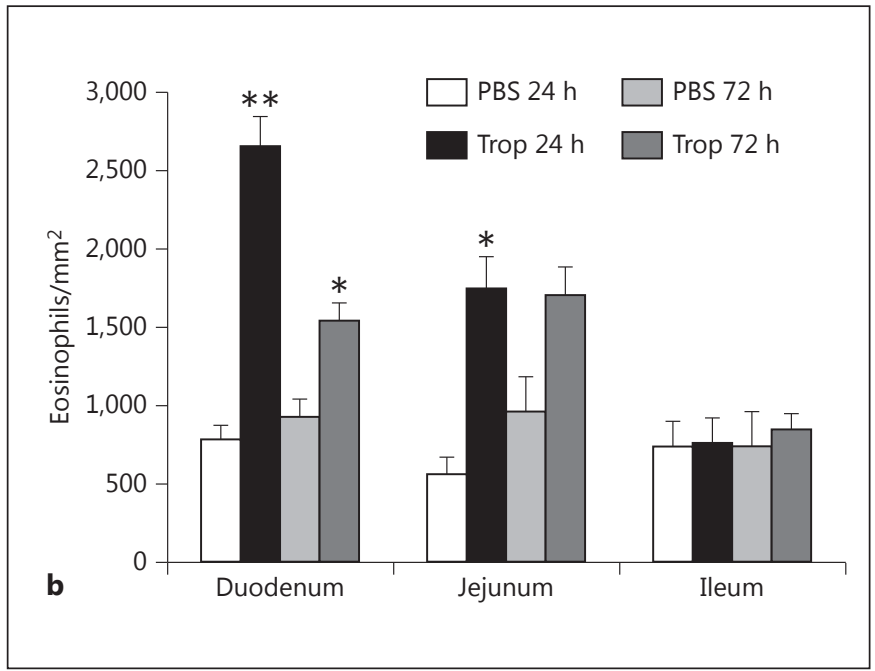

$\mathrm{p}<0.05$; fig. 5b) of tropomyosin-sensitized mice when compared with control mice. There were no differences in the level of Casp3+ epithelial cells in the duodenum between tropomyosin-sensitized mice and control mice. 


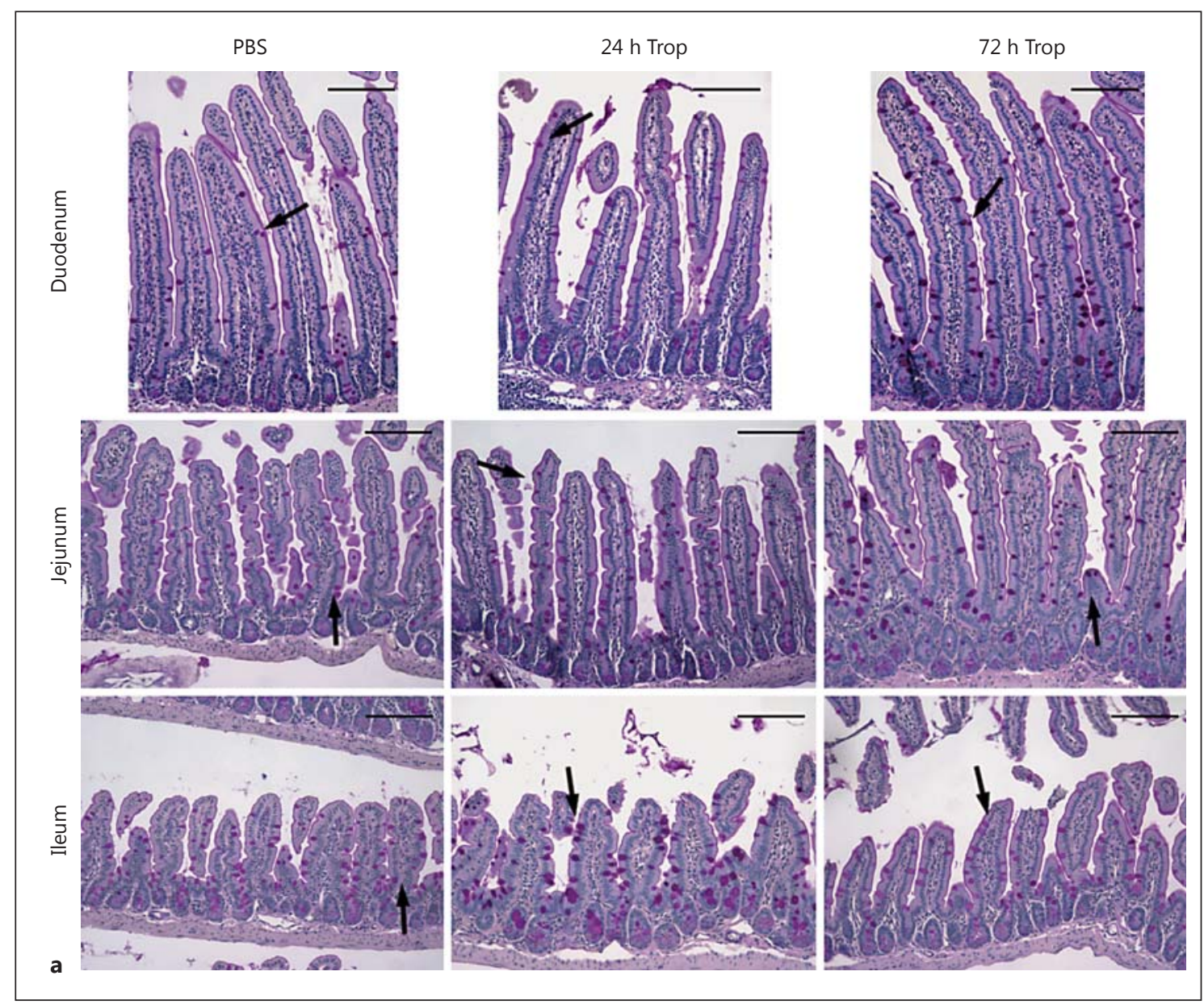

Fig. 4. Sensitizing and challenging mouse with tropomyosin resulted in goblet cell hyperplasia (arrows indicate goblet cells stained purple-red in periodic acid-Schiff) in the small intestine mucosa. a Representative sections of the duodenum, jejunum and ileum of a PBS control mouse (left) and tropomyosin-sensitized mice, 24 (middle) and $72 \mathrm{~h}$ (right) after challenge. $\mathbf{b}$ Percentage of goblet cells over epithelial cells in the three parts of the small intestine of control $(n=3)$ and sensitized mice $(n=6) .{ }^{*} p<0.05$, ** $\mathrm{p}<0.005$ compared with control mice. Data are expressed as the mean \pm SEM. Scale bars $=100 \mu \mathrm{m}$.

Skewed Intestinal Th1/Th2 in Tropomyosin-Sensitized Mice

At $24 \mathrm{~h}$ after challenge, tropomyosin-sensitized mice demonstrated significant higher IL-4 (about 4-fold; $\mathrm{p}<$ 0.05; fig. 6a) and IL-6 (about 4.5 -fold; p < 0.05) mRNA 


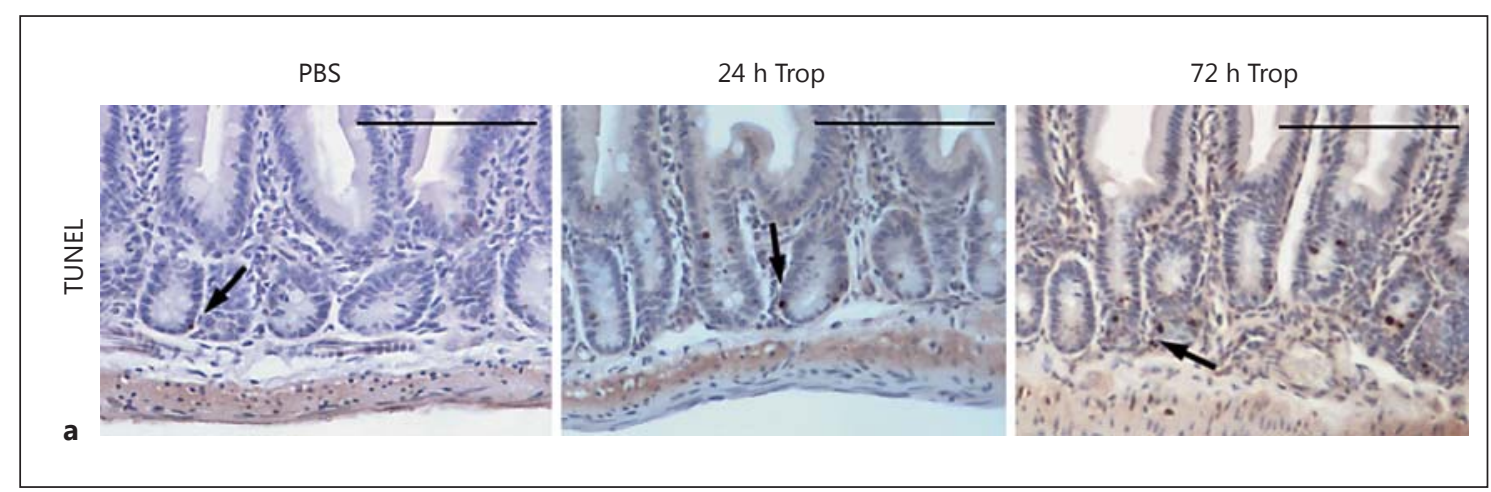

Fig. 5. Sensitizing and challenging mouse with tropomyosin resulted in increased apoptotic cells (arrows indicate the apoptotic cell nucleus stained brown in TUNEL staining) in the crypts. a Representative sections of the duodenum of a PBS control mouse (left) and tropomyosin-sensitized mice, 24 (middle) and $72 \mathrm{~h}$ (right) after challenge. b TUNEL+ cell numbers per 100 crypts in the duodenum control $(\mathrm{n}=3)$ and sensitized mice $(\mathrm{n}=6)$. ${ }^{*} \mathrm{p}<$ 0.05 , compared with control mice. Data are expressed as the mean \pm SEM. Scale bars $=100 \mu \mathrm{m}$.

sion for any of these cytokines were observed at $72 \mathrm{~h}$ after challenge.

\section{Elevation of Intestinal $m M C P-1 m R N A$ Expression at} $72 \mathrm{~h}$ after Challenge

There was no difference in $\mathrm{mMCP}-1$ by quantitative RT-PCR between the sensitized mice and the control mice at $24 \mathrm{~h}$ after challenge. However, a significantly higher mMCP-1 level was observed among the Met e 1 -sensitized mice at $72 \mathrm{~h}$ after challenge when compared with the control mice (about 2.5 -fold; $\mathrm{p}<0.05$; fig. $6 \mathrm{~b}$ ).

\section{Discussion}

Mucosal defense by gut-associated lymphoid tissues is responsible for the induction of food tolerance as well as intestinal inflammation from food allergens [28-30]. An example of a food item that can cause an allergic reaction is shellfish. The prevalence of shellfish allergy has in-

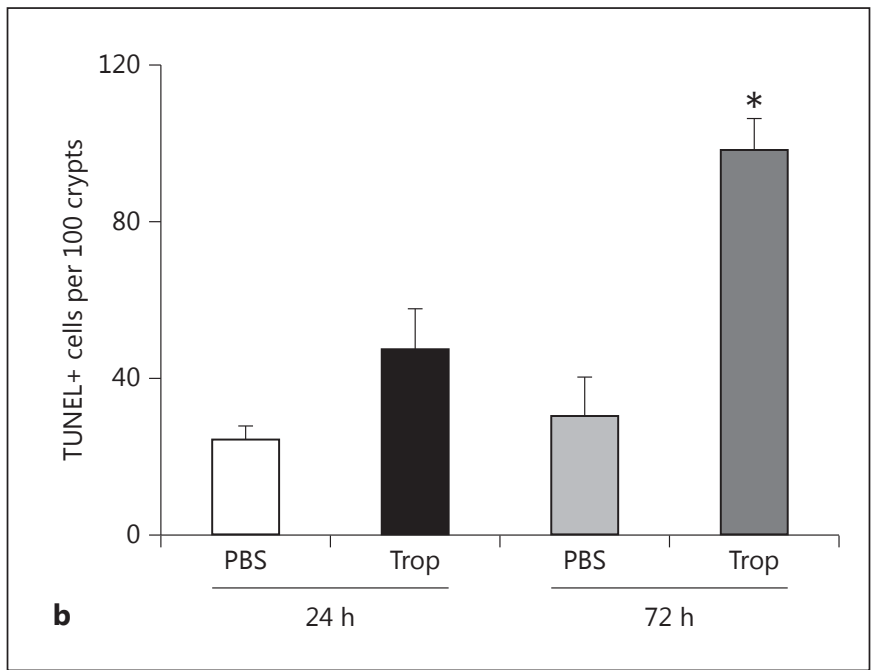

creased significantly recently - in part due to increased consumption. Nevertheless, few studies have concentrated on the effects of shellfish hypersensitivity, especially on involvement of the gut. Using an established animal model of shellfish hypersensitivity, we have conducted a comprehensive examination of the immunological changes of the gut after allergen ingestion. In particular, we applied the Swiss roll method [31] to examine the changes in the intestine of mice with shrimp tropomyosin-induced hypersensitivity. This technique provides a systematic and comprehensive approach to characterizing the histological changes of the entire small intestine in a continuous fashion as compared to conventional studies, which only analyze a small segment from different regions [32].

Our data show that sensitization with shrimp tropomyosin induces the accumulation of immune effector cells, including mast cells and eosinophils in the small intestine. Since it was demonstrated in the model previously that the use of an irrelevant protein control did not 
Fig. 6. Relative mRNA expressions of selected target genes normalized to HPRT1 in tropomyosin-sensitized and challenged mice and control mice sacrificed 24 (a) or $72 \mathrm{~h}$ (b) after challenge. Data, expressed as the mean \pm SEM, were obtained from 3 mice in the PBS group and 4-6 mice in the Trop group. ${ }^{*} \mathrm{p}<0.05$ compared with control mice.

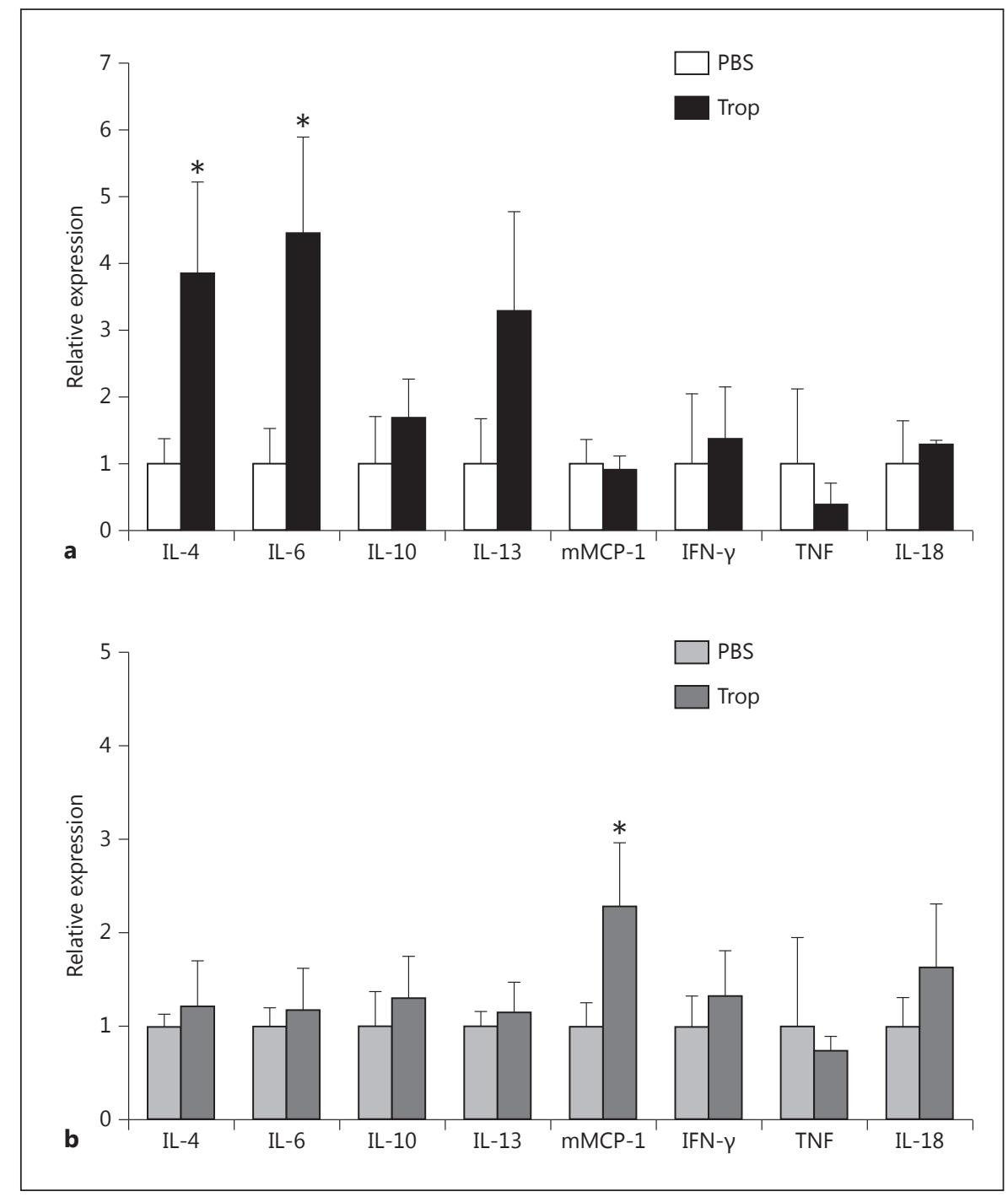

induce rMet e 1-specific IgE responses, only a PBS control group was used in this study [19]. Mast cells have long been regarded as one of the major effector cell types of food allergy and intestinal mast cell levels have been shown to correlate with the severity of symptoms in mouse models of food allergy [20,33]. Eosinophils constitute another principal effector cell type that induces gastrointestinal tissue injury and disease pathogenesis through the release of various toxic granule proteins, lipid mediators and proinflammatory cytokines [34]. Compared with other allergy models, the accumulation of inflammatory cells in these mice does not require repetitive intragastric challenge $[15,35]$.

The gastrointestinal tract mucus layer is the front line of innate host defense [36]. The accumulation of mucus- secreting goblet cells among the gut epithelium in tropomyosin-sensitized mice is similar to that reported in other animal models of food allergies $[37,38]$. To determine if the elevated percentage of goblet cells over intestinal epithelial cells was associated with increased cell proliferation, we conducted BrdU tracing analysis to examine crypt cell proliferation [25]. Interestingly, the percentage of proliferating cells in the crypts was unchanged, but the migration distance of epithelial cells from the crypts was higher at $72 \mathrm{~h}$ after challenge when compared to that in the control mice. We note that increased proliferation and migration rates of epithelial cells from the crypts are often associated with inflammation in the small bowel [39]. Epithelial cells are produced in the crypts and migrate up the crypt-villus axis until they are shed from the 
tip of the villi [40]. Inflammation in the intestine leads to increased loss of epithelial cells and requires a higher proliferation rate to replenish the cells [41]. In a murine model of egg allergy, Song et al. [15] reported a higher percentage of proliferating cells in the crypts of sensitized mice than in nonsensitized mice using the BrdU tracing method. This difference noted between our study and their study may be partly attributed to the difference in timing of the BrdU injection before sacrifice. Regardless, the increase in intestinal cell proliferation is highly likely to be involved in food allergy and warrants further investigation. Furthermore, a higher proportion of apoptotic crypt cells in sensitized mice $72 \mathrm{~h}$ after challenge suggests a progressive and destructive allergic response in the intestine.

Studies on regional differences in the gut upon food allergen sensitization are limited. Most studies using food allergy models have focused on the jejunum [1416]. Interestingly, the most severely affected region of the gut in our animal model of shrimp tropomyosin hypersensitivity was the duodenum. Notably, mast cells and eosinophils accumulated in patches within the mucosa and there was a gradual decrease in these three cell types moving from the duodenum to the jejunum and ileum. Similar to our observations, a fish allergy study reported a significant increase in eosinophils in the duodenum only while eosinophil cell counts from the jejunum and ileum are low [42]. Lin et al. [11] characterized immune changes in the duodenum from allergic patients that included an increase in IgE-bearing cells and infiltration of eosinophils and $\mathrm{CD} 3+, \mathrm{CD} 4+$ and CD8+ cells. Likewise, using an OVA-induced mouse model for egg allergy, Saldanha et al. [37] reported that food allergens induced a significant increase in intestinal vascular permeability in the proximal small intestine, including the duodenum and proximal jejunum, but not the distal jejunum or ileum. These studies, taken together, suggest that the duodenum is highly susceptible. The regional variations of the gut in food allergies may be partly explained by differences in the nutrient adsorption capacity of the regions and their resident microbiota $[43,44]$.

In addition to regional differences, our results demonstrate the presence of early and delayed hypersensitivity reactions. The higher number of mast cells and goblet cells in the duodenum at $72 \mathrm{~h}$ after challenge when compared with $24 \mathrm{~h}$ after challenge in the sensitized mice and increased mMCP-1 mRNA expression observed $72 \mathrm{~h}$ after challenge indicate the occurrence of a late-phase hypersensitive response. The functional significance of the accumulation of mast cells in these processes is largely unknown. In allergy, apart from their classic role in eliciting the early phase, mast cells also have a repair/remodeling function in the late and chronic stages of pathogenesis $[45,46]$. In addition, our results show that the number of eosinophils in the duodenum of sensitized mice is lower at $72 \mathrm{~h}$ after challenge when compared to $24 \mathrm{~h}$ after challenge, which is consistent with the results obtained in the OVA-induced mice model [37].

It is important to note that tropomyosin-sensitized mice not only developed characteristics of intestinal inflammation related to hypersensitivity, but 5 out of 12 mice fed with tropomyosin also developed diarrhea after a single challenge. On the other hand, repeated oral gavage and systemic priming are required to trigger the onset of allergic diarrhea in other sensitized mice models of food allergy [20,30,38,47]. Although proven to be antigen specific, allergic diarrhea induced by repeated oral challenge is regarded as unnatural. Wang et al. [16] reported a $20 \%$ incidence of diarrhea after one challenge. Moreover, Knight et al. [35] reported an incidence of $100 \%$ after a single dose challenge in their OVA murine model, while lower allergen doses reduced the incidence.

To dissect the Th1/Th2 cytokine profile at the site of inflammation, we examined the local cytokine responses in the gut of shrimp tropomyosin-sensitized mice. While the expression of the Th 2 cytokines, IL- 4 along with the proinflammatory cytokine, IL-6, was higher in the sensitized mice, the expression of the Th1 cytokines (IFN- $\gamma$, IL-18 and TNF) and anti-inflammatory cytokine, IL-10, was similar to that in the control mice. Consistent with other animal models with allergic diarrhea $[48,49]$, our findings confirm the important role of Th2 cytokines in food allergy. Furthermore, these results are consistent with the higher level of Th2 cytokines, IL-4 and IL-6, and unaltered or lower levels of the Th1 cytokine, IFN- $\gamma$, in the intestinal mucosa of patients and mice with food allergy $[11,38,50,51]$. In light of our previous observation of IL-17 in this animal model and the significance of altered Th17 responses in food allergy [19, 52], future studies should be directed toward examining the contribution and interplay of Th1/Th2 as well as Th17 response in food allergies. Finally, because subjects who have outgrown their peanut allergy and those who are under potential treatment for allergies both exhibit a shifted Th1/Th2 cytokine profile, clearly further studies on cytokine profiles should be pursued [53-57].

To our knowledge, this is the first report on regional immunological responses in the intestine after shrimp al-
38

Int Arch Allergy Immunol 2015;167:29-40 DOI: $10.1159 / 000431228$
Lam/Tong/Kwan/Tsuneyama/Shu/Leung/ $\mathrm{Chu}$ 
lergen challenges. Moreover, our animal model allows us to accomplish studies that cannot be performed using human subjects. The demonstration of gut eosinophil, mast cell and goblet cell hyperplasia along with skewed Th2 cytokine profiles in this model of shrimp allergy will enhance future studies in allergic inflammation, oral tolerance mechanisms and therapeutic interventions for shrimp-allergic patients.

\section{Acknowledgements}

We thank Dr. J.J. Lee (Mayo Clinic) for the provision of the anti-mouse major basic protein monoclonal antibody, Mr. K.C. Cheung, Mr. N.Y.H. Leung and Ms. C.Y.Y. Wai (The Chinese University of Hong Kong) for technical assistance, and Dr. David Wilmshurst (The Chinese University of Hong Kong) for editorial comments on the manuscript. This study was fully supported by a grant from the Research Grants Council, HKSAR, China (project no. CUHK463911).

\section{References}

1 Soller L, Ben-Shoshan M, Harrington DW, Fragapane J, Joseph L, St Pierre Y, Godefroy SB, La Vieille S, Elliott SJ, Clarke AE: Overall prevalence of self-reported food allergy in Canada. J Allergy Clin Immunol 2012;130: 986-988.

2 Shek LPC, Cabrera-Morales EA, Soh SE, Gerez I, Ng PZ, Yi FC, Ma S, Lee BW: A population-based questionnaire survey on the prevalence of peanut, tree nut, and shellfish allergy in 2 Asian populations. J Allergy Clin Immunol 2010;126:324-331.

3 McGowan EC, Keet CA: Prevalence of selfreported food allergy in the National Health and Nutrition Examination Survey (NHANES) 2007-2010. J Allergy Clin Immunol 2013;132:1216-1219.

4 Arruda LK: The right timing for shrimp tropomyosins. Int Arch Allergy Immunol 2013;160:331-333.

5 Pedrosa M, Boyano-Martinez T, Garcia-Ara C, Quirce S: Shellfish allergy: a comprehensive review. Clin Rev Allergy Immunol 2014, Epub ahead of print.

6 Rivas MF: Food allergy in Alergológica 2005. J Investig Allergol Clin Immunol 2009; 19:37-44.

7 Arvola T, Ruuska T, Keranen J, Hyoty H, Salminen S, Isolauri E: Rectal bleeding in infancy: clinical, allergological, and microbiological examination. Pediatrics 2006;117:760-768.

8 Hagel AF, deRossi T, Zopf Y, Konturek P, Dauth W, Kressel J, Hahn EG, Raithel M: Mast cell tryptase levels in gut mucosa in patients with gastrointestinal symptoms caused by food allergy. Int Arch Allergy Immunol 2013;160:350-355.

9 Hagel AF, de Rossi TM, Zopf Y, Lindner AS, Dauth W, Neurath MF, Raithel M: Smallbowel capsule endoscopy in patients with gastrointestinal food allergy. Allergy 2012;67: 286-292.

10 Chen X, Song CH, Liu ZQ, Feng BS, Zheng PY, Li P, In SH, Tang SG, Yang PC: Intestinal epithelial cells express galectin-9 in patients with food allergy that plays a critical role in sustaining allergic status in mouse intestine. Allergy 2011;66:1038-1046.
11 Lin XP, Magnusson J, Ahlstedt S, DahlmanHoglund A, Hanson LLA, Magnusson O, Bengtsson U, Telemo E: Local allergic reaction in food-hypersensitive adults despite a lack of systemic food-specific IgE. J Allergy Clin Immunol 2002;109:879-887.

12 Ahrens B, Quarcoo D, Buhner S, Reese G, Vieths S, Hamelmann E: Development of an animal model to evaluate the allergenicity of food allergens. Int Arch Allergy Immunol 2014;164:89-96.

13 Oyoshi MK, Oettgen HC, Chatila TA, Geha RS, Bryce PJ: Food allergy: insights into etiology, prevention, and treatment provided by murine models. J Allergy Clin Immunol 2014; 133:309-317.

14 Ganeshan K, Neilsen CV, Hadsaitong A, Schleimer RP, Luo X, Bryce PJ: Impairing oral tolerance promotes allergy and anaphylaxis: a new murine food allergy model. J Allergy Clin Immunol 2009;123:231-238.e4.

15 Song DJ, Cho JY, Miller M, Strangman W, Zhang M, Varki A, Broide DH: Anti-Siglec-F antibody inhibits oral egg allergen induced intestinal eosinophilic inflammation in a mouse model. Clin Immunol 2009;131:157169.

16 Wang M, Okamoto M, Domenico J, Han J, Ashino S, Shin YS, Gelfand EW: Inhibition of Pim1 kinase prevents peanut allergy by enhancing Runx3 expression and suppressing $\mathrm{T}_{\mathrm{H}} 2$ and $\mathrm{T}_{\mathrm{H}} 17 \mathrm{~T}$-cell differentiation. J Allergy Clin Immunol 2012;130:932-944.

17 Leung PS, Chu KH, Chow WK, Ansari A, Bandea CI, Kwan HS, Nagy SM, Gershwin ME: Cloning, expression, and primary structure of Metapenaeus ensis tropomyosin, the major heat-stable shrimp allergen. J Allergy Clin Immunol 1994;94:882-890.

18 Reese G, Jeoung BJ, Daul CB, Lehrer SB: Characterization of recombinant shrimp allergen Pen a 1 (tropomyosin). Int Arch Allergy Immunol 1997;113:240-242.

19 Leung PS, Lee YS, Tang CY, Kung WY, Chuang YH, Chiang BL, Fung MC, Chu KH: Induction of shrimp tropomyosin-specific hypersensitivity in mice. Int Arch Allergy Immunol 2008;147:305-314.
20 Brandt EB, Strait RT, Hershko D, Wang Q, Muntel EE, Scribner TA, Zimmermann N, Finkelman FD, Rothenberg ME: Mast cells are required for experimental oral allergeninduced diarrhea. J Clin Invest 2003;112: 1666-1677.

21 Ostanin DV, Pavlick KP, Bharwani S, Souza DD, Furr KL, Brown CM, Grisham MB: T cell-induced inflammation of the small and large intestine in immunodeficient mice. Am J Physiol Gastrointest Liver Physiol 2006; 290:G109-G119.

22 Friend DS, Ghildyal N, Austen KF, Gurish MF, Matsumoto R, Stevens RL: Mast cells that reside at different locations in the jejunum of mice infected with Trichinella spiralis exhibit sequential changes in their granule ultrastructure and chymase phenotype. J Cell Biol 1996; 135:279-290

23 Hernandes L, Pereira LC, Alvares EP: Goblet cell number in the ileum of rats denervated during suckling and weaning. Biocell 2003;27: 347-351.

24 Kumada T, Tsuneyama K, Hatta H, Ishizawa S, Takano Y: Improved 1-h rapid immunostaining method using intermittent microwave irradiation: practicability based on 5 years application in Toyama Medical and Pharmaceutical University Hospital. Mod Pathol 2004;17:1141-1149.

$25 \mathrm{Wu}$ D, Ahrens R, Steinbrecher H, Rothenberg ME, Groschwitz NF, Foster PS, Steinbrecher KA, Rothenberg ME, Shroyer NF, Matthaei KI, Finkelman FD, Hogan SP: Interleukin-13 (IL-13)/IL-13 receptor $\alpha 1$ (IL-13R $\alpha 1$ ) signaling regulates intestinal epithelial cystic fibrosis transmembrane conductance regulator channel-dependent $\mathrm{Cl}^{-}$secretion. J Biol Chem 2011;286:13357-13369.

26 Vyas D, Robertson CM, Stromberg PE, Martin JR, Dunne WM, Houchen CW, Barrett TA, Ayala A, Perl M, Buchman TG, Coopersmith CM: Epithelial apoptosis in mechanistically distinct methods of injury in the murine small intestine. Histol Histopathol 2007;22: 623-630. 
27 Bhanja P, Saha S, Kabarriti R, Liu L, RoyChowdhury N, Roy-Chowdhury J, Sellers RS, Alfieri AA, Guha C: Protective role of R-spondin1, an intestinal stem cell growth factor, against radiation-induced gastrointestinal syndrome in mice. PLoS One 2009;4:e8014.

28 Shan M, Gentile M, Yeiser JR, Walland AC, Bornstein VU, Chen K, He B, Cassis L, Bigas A, Cols M, Comerma L, Huang B, Blander JM, Xiong H, Mayer L, Berin C, Augenlicht LH, Velcich A, Cerutti A: Mucus enhances gut homeostasis and oral tolerance by delivering immunoregulatory signals. Science 2013;342: 447-453.

29 Chahine BG, Bahna SI: The role of the gut mucosal immunity in the development of tolerance versus development of allergy to food. Curr Opin Allergy Clin Immunol 2010;10: 394-399.

30 Kim JS, Sampson HA: Food allergy: a glimpse into the inner workings of gut immunology. Curr Opin Gastroenterol 2012;28:99-103.

31 Moolenbeck C, Ruitenberg EJ: The 'Swiss roll': a simple technique for histological studies of the rodent intestine. Lab Anim 1981;15: 57-59.

32 Osterheld MC, Meagher-Villemure K, Ciola AM, Martin P, Vilas D, Meyrat BJ: Hirschsprung's disease: the 'Swiss roll' technique revisited. Pediatr Surg Int 2009;25:573578.

33 Ahrens R, Osterfeld H, Wu D, Chen CY, Arumugam M, Groschwitz K, Strait R, Wang YH, Finkelman FD, Hogan SP: Intestinal mast cell levels control severity of oral antigen-induced anaphylaxis in mice. Am J Pathol 2012;180: 1535-1546.

34 Rothenberg ME, Mishra A, Brandt EB, Hogan SP: Gastrointestinal eosinophils. Immunol Rev 2001;179:139-155.

35 Knight AK, Blazquez AB, Zhang S, Mayer L, Sampson HA, Berin MC: CD4 T cells activated in the mesenteric lymph node mediate gastrointestinal food allergy in mice. Am J Physiol Gastrointest Liver Physiol 2007;293: G1234-G1243.

36 Kim YS, Ho SB: Intestinal goblet cells and mucins in health and disease: recent insights and progress. Curr Gastroenterol Rep 2010; 12:319-330.

37 Saldanha JCS, Gargiulo DL, Silva SS, CarmoPinto FH, Andrade MC, Alvarez-Leite JI, Teixeira MM, Cara DC: A model of chronic
IgE-mediated food allergy in ovalbumin-sensitized mice. Braz J Med Biol Res 2004;37: 809-816.

38 Wang M, Takeda K, Shiraishi Y, Okamoto M, Dakhama A, Joetham A, Gelfand EW: Peanut-induced intestinal allergy is mediated through a mast cell-IgE-FceRI-IL-13 pathway. J Allergy Clin Immunol 2010;126:306$316 \mathrm{e} 12$.

39 MacDonald TT: Epithelial proliferation in response to gastrointestinal inflammation. Ann NY Acad Sci 1992;664:202-209.

40 Savilahti E: Food-induced malabsorption syndromes. J Pediatr Gastroenterol Nutr 2000;30:S61-S66.

41 Ruemmele FM, Seidman EG, Lentze MJ: Regulation of intestinal epithelial cell apoptosis and the pathogenesis of inflammatory bowel disorders. J Pediatr Gastroenterol Nutr 2002; 34:254-260.

42 Pali-Scholl I, Yildirim AO, Ackermann U, Knauer T, Becker C, Garn H, Renz H, JensenJarolim E, Fehrenbach H: Anti-acids lead to immunological and morphological changes in the intestine of BALB/c mice similar to human food allergy. Exp Toxicol Pathol 2008;60: 337-345.

43 Karlsson J, Pütsep K, Chu H, Kays RJ, Bevins $\mathrm{CL}$, Andersson $\mathrm{M}$ : Regional variations in $\mathrm{Pa}-$ neth cell antimicrobial peptide expression along the mouse intestinal tract. BMC Immunol 2008;9:37.

44 Hao WL, Lee YK: Microflora of the gastrointestinal tract: a review. Methods Mol Biol 2004;268:491-502.

45 Bischoff SC, Sellge G: Mast cell hyperplasia: role of cytokines. Int Arch Allergy Immunol 2002;127:118-122.

46 Pawankar R, Yamagishi S, Takizawa R, Yagi T: Mast cell-IgE and mast cell-structural cell interactions in allergic airway disease. Curr Drug Targets Inflamm Allergy 2003;2:303312.

47 Kweon MN, Yamamoto M, Kajiki M, Takahashi I, Kiyono H: Systemically derived large intestinal $\mathrm{CD} 4^{+} \mathrm{Th} 2$ cells play a central role in STAT6-mediated allergic diarrhea. J Clin Invest 2000;106:199-206.

48 Mathias CB, Hobson SA, Garcia-Lloret M, Lawson G, Poddighe D, Freyschmidt EJ, Xing W, Gurish MF, Chatila TA, Oettgen HC: IgEmediated systemic anaphylaxis and impaired tolerance to food antigens in mice with en- hanced tolerance to food antigens in mice with enhanced IL-4 receptor signaling. J Allergy Clin Immunol 2011;127:795-805.e6.

49 Kucuk ZY, Strait R, Khodoun MV, Mahler A, Hogan S, Finkelman FD: Induction and suppression of allergic diarrhea and systemic anaphylaxis in a murine model of food allergy. J Allergy Clin Immunol 2012;129:13432348.

50 Coeffier M, Lorentz A, Manns MP, Bischoff SC: Epsilon germ-line and IL-4 transcripts are expressed in human intestinal mucosa and enhanced in patients with food allergy. Allergy 2005;60:822-827.

51 Cardoso CR, Teixeira G, Provinciatto PR, Godoi DF, Ferreira BR, Milanezi CM, Ferraz DB, Rossi MA, Cunha FQ, Silva JS: Modulation of mucosal immunity in a murine model of food-induced intestinal inflammation. Clin Exp Allergy 2008;38:338-349.

52 Dhuban KB, d'Hennezel E, Ben-Shoshan M, McCusker C, Clarke A, Fiset P, Mazer B, Piccirillo CA: Altered T helper 17 responses in children with food allergy. Int Arch Allergy Immunol 2013;162:318-322.

53 Castro MS, Azpiroz MB, Molina MA, Mourelle AC, Alaniz FS, Maldonado AM, Manghi MA: Preliminary studies on the prevention of the ovalbumin-induced allergic response by Enterococcus faecalis CECT7121 in mice. Int Arch Allergy Immunol 2012;157:11-20.

54 Mondoulet L, Dioszeghy V, Vanoirbeek JA, Nemery B, Dupont C, Benhamou PH: Epicutaneous immunotherapy using a new epicutaneous delivery system in mice sensitized to peanuts. Int Arch Allergy Immunol 2011;154: 299-309.

55 Rupa P, Nakamura S, Katayama S, Mine Y: Attenuation of allergic immune response phenotype by mannosylated egg white in orally induced allergy in Balb/c mice. J Agric Food Chem 2014;62:9479-9487.

56 Schiavi E, Barletta B, Butteroni C, Corinti S, Boirivant M, Di Felice G: Oral therapeutic administration of a probiotic mixture suppresses established Th2 responses and systemic anaphylaxis in a murine model of food allergy. Allergy 2011;66:499-508.

57 Turcanu V, Maleki SJ, Lack G: Characterization of lymphocyte responses to peanuts in normal children, peanut-allergic children, and allergic children who acquired tolerance to peanuts. J Clin Invest 2003;111:1065-1072. 